\title{
Reproductive Effects of some trace elements On Male Infertility In Thi-Qar Governorate/Iraq
}

\author{
Malak .A. Naeem \& Sajid .H. Guzar* \\ Enaas .S. Jawad** \\ * Department of Chemistry, Collage of Science \\ ** Department of , College of Medicine, University of Thi-Qar \\ **enass-s@utq.edu.iq
}

\begin{abstract}
The present study was carried out on 50 infertile males whose age range between (19-49) year and 16 male, who were apparently healthy, as a control group whose age range between (18-49) year.

The studied males were classified into two groups according to their case health to infertile male and fertile male.

The parameters measured were seminal fluid levels lead, cadmium, zinc, copper, chromium, magnesium, iron and cobalt. These parameters were estimated in seminal fluid of patients and control group.

The results shown a highly significant different in levels of lead element $\left(7.541^{\mathrm{a}}\right.$, $\left.0.056^{\mathrm{b}}\right)$, cadmium element $\left(0.023^{\mathrm{a}}, 0.007^{\mathrm{b}}\right)$, zinc element $\left(1.275^{\mathrm{a}}, 0.054^{\mathrm{b}}\right)$, chromium element $\left(0.408^{\mathrm{a}}, 0.090^{\mathrm{b}}\right)$, iron element $\left(2.172^{\mathrm{a}}, 0.148^{\mathrm{b}}\right)$, cobalt element $\left(0.022^{\mathrm{a}}, 0.008^{\mathrm{b}}\right)$, in primary infertile males when compared with in secondary infertile males(a: primary, b:secondry).The results shown a highly significant different in levels of lead element, cadmium element, zinc element, chromium element, iron element, cobalt element, in infertile men when compared with fertile men.
\end{abstract}

The results illustrated highest level of concentrations elements in measurements was lead element levels and cadmium levels in infertile males when compared with control group.

As well as lower levels of concentration metals was cobalt element levels in infertile males when compared with control group.

Keywords: Seminal fluid, Trace Element, Azoospremia. 


\section{Introduction}

Infertility is typically defined as failure to conceive within a certain period of time For the male, this definition is particularly problematic, as it relies on an outcome for his female partner, who may have reproductive issues of her own. Fecundity is the term used for the probability of a women in sexually active couple becoming pregnant per menstrual cycle without contraception. It is customary to define infertility clinically as the inability of couple trying to conceive to do so within one year. infertility can be classified as primary infertility when no pregnancy has ever occurred or secondary if it occurred after one or more pregnancy. Approximately $15 \%$ of couples attempting their first conception meet with a failure, and another $10 \%$ face infertility (1).

Data available over the past 20 years reveal that in approximately $30 \%$ - $50 \%$ of the cases of infertility, the cause is found in the man alone, and another $20 \%$, the causes are found in both (2). And in another 50\%-70\%, the causes are found in female alone (3).human fertility is complex, it depends upon synergy of male and female reproductive competence in which physiological, genetic, behavioral and environmental factors has limited our understanding of the mechanisms of conception and fertility, and the problem is compounded by the diversity of reproductive physiology among mammals, which limited extrapolation from animal models. Historical interest and research in human fertility have been motivated by several goals, including diagnosis and treatment of infertility (5).

improvements in contraceptive technology and, more recently, concerns of environmental and occupational exposure, In the majority of cases of male infertility the cause of impaired semen parameters is unknown (4).

Azoospermia (absence of sperm) or significant oligozoospermia (sperm concentration < 15 million per $\mathrm{ml}$ ) may be associated with small soft testes and raised (FSH) levels. Histological changes within the tubules, such as the absence or reduced number of germ cells may be patchy and non-specific (4).

Asthenozoospermia implies impaired motility (less than 50\%). Absent or very poor motility in sperm may be caused by structural abnormalities such as the absence of dynein arms, radial spokes and dysplasia of the fibrous sheath (5).

Teratozoospermia is the term used to describe abnormal sperm morphology on microscopy. Although the assessment is inevitably subjective, observance of the strict criteria can lead to a degree of consistency of 


\section{Email:utjmed@utq.edu.iq}

reporting, at least within each laboratory. Morphology is believed to reflect immaturity and functional integrity of sperm and has been related to acrosomes defects and sperm motility (6).

A varicocele is a group of dilated veins in the pampiniform plexus of the spermatic cord. On examination, it is visible as a tangle of distended blood vessels in the scrotum. Usually left sided, varicoceles develop at puberty and affect $15 \%$ of otherwise healthy men (3).

A number of heavy metals, chemicals and pesticides have been associated with deranged spermatogenesis. Tobacco, cannabis, alcohol and lifestyle factors such as wearing tight underwear have also been linked with male infertility. Evidence regarding some these associations is conflicting (7).

These heavy metals could adversely affect the male reproductive system; either by causing hypothalamicpituitary axis disruption or by directly affecting spermatogenesis, resulting in impair semen quality. A number of commonly used drugs can impair semen quality. Cancer chemotherapy it action alkylating agents cause irreversible damage (8).

Hormone treatment it action high dose corticosteroids, androgens ,anti- androgens ,estrogens and (LHRH) agonist. Cimetidine may competitively inhibit androgen effect on the receptor. Sulphasalazine can cause impairment of sperm quality by direct toxicity. Colchicine cause depression of fertility by direct toxicity to spermatogenesis (9).

The male reproductive system is very sensitive to many factors which are contributed to decrease of sperm quality. These factors are environmental pollution, nutrition, diseases and others (10).

The heavy metals exposure is associated with impaired semen quality due to their direct effect on testicular function as well as hormonal alteration (11).

Lead appears in homes in many forms as lead piping, lead -containing solders, paints, ceramic glazes, base metal utensils and fixtures (12).

Also, cream powder, lipstick and hair color have lead. Agricultural soil contamination may be responsible for lead found in many herbal medicines and cigarettes. On the contrary, their detrimental effects on physiological, biochemical, and behavioral dysfunctions have been documented in animals and humans by several investigators (13). 


\section{Materials and Methods}

Table (1): chemicals with their suppliers company and purity and molecular weight.

\begin{tabular}{|l|l|l|l|l|}
\hline Number & Chemicals & Purity & Molecular weight & $\begin{array}{l}\text { Supplies } \\
\text { company }\end{array}$ \\
\hline 1 & Nitric acid & $\mathbf{7 0 \%}$ & $\mathbf{6 3 . 0 1}$ & Scharlau \\
\hline $\mathbf{2}$ & Perchloric acid & $\mathbf{7 1 \%}$ & $\mathbf{1 0 0 . 4 5}$ & Scharlau \\
\hline
\end{tabular}

Table (2): classified two group

\begin{tabular}{|l|l|l|}
\hline $\mathrm{n}>15 * 10^{6}$ & Fertile men & Group (1) \\
\hline $\mathrm{n}<15^{*} 10^{6}$ & Infertile men & Group (2) \\
\hline
\end{tabular}

\subsection{Design of study}

This study was conducted at Al-Hussein teaching hospital in infertility unit Thi-Qar governorate. The study was carried out in the unit of the Laboratory Department of Clinical Biochemistry during the period collect from 1 \9\2015 to $29 \backslash 5 \backslash 2016$. Informed consent was obtained verbally from all participant . A total of thirty four men with infertility of the ages $18-49$ years. To compare the results, sixteen fertile men. The present study including (50) men, which were divided into general groups:

- Control group (fertile men): including (16) apparently fertile men.

- Case group (infertile men): including (34) infertile men who infertility.

2.2 Collection of semen samples and semen analysis

Semen samples were collected after masturbation into sterile cups following three days sexual abstinence. After 30 min of liquefaction, the standard semen parameters were immediately evaluated according to the world health organization (WHO). Specimens were analyzed for spermatozoa morphology using a modified papanicolaou stain. Sperm samples were stored at $-20 \mathrm{c}$ and subsequently mineralized in the laboratory. 
Table (2-1) Shows the device running AAS conditions and conditions hollow cathode lamps.

\begin{tabular}{|c|c|c|c|c|c|c|}
\hline Element & $\lambda_{\max }$ & Background & $\begin{array}{l}\text { Flame } \\
\text { type }\end{array}$ & $\begin{array}{c}\text { Sensitivity } \\
\text { (ppm) }\end{array}$ & $\begin{array}{c}\text { Detection } \\
\text { limit } \\
(\mathbf{p p m})\end{array}$ & $\begin{array}{c}\text { Working } \\
\text { range } \\
(p p m)\end{array}$ \\
\hline $\mathrm{Cr}$ & 357.9 & $\mathbf{D}_{2} / \mathrm{SR}$ & $\begin{array}{c}\text { Air/ } \\
\text { Acetylene }\end{array}$ & 0.05 & 0.005 & 0.04-8 \\
\hline Fe & 248.3 & $\mathrm{D}_{2} / \mathrm{SR}$ & $\begin{array}{c}\text { Air/ } \\
\text { Acetylene }\end{array}$ & 0.05 & 0.0046 & $0.03-8$ \\
\hline Mg & 285.2 & $\mathbf{D}_{2} / \mathrm{SR}$ & $\begin{array}{c}\text { Air/ } \\
\text { Acetylene }\end{array}$ & 0.003 & 0.0018 & 0.007-0.4 \\
\hline Cd & 228.8 & $\mathrm{D}_{2} / \mathrm{SR}$ & $\begin{array}{c}\text { Air/ } \\
\text { Acetylene }\end{array}$ & 0.012 & 0.0028 & $0.02-2.2$ \\
\hline $\mathbf{Z n}$ & 213.9 & $\mathrm{D}_{2} / \mathrm{SR}$ & $\begin{array}{c}\text { Air/ } \\
\text { Acetylene }\end{array}$ & 0.01 & 0.003 & $0.01-3$ \\
\hline $\mathrm{Cu}$ & 324.7 & $\mathrm{D}_{2} / \mathrm{SR}$ & $\begin{array}{c}\text { Air/ } \\
\text { Acetylene }\end{array}$ & 0.03 & 0.004 & $0.02-6$ \\
\hline Co & 240.7 & $\mathbf{D}_{2} / \mathbf{S R}$ & $\begin{array}{c}\text { Air/ } \\
\text { Acetylene }\end{array}$ & 0.05 & 0.01 & $0.04-8$ \\
\hline $\mathbf{P b}$ & 217 & $\mathbf{D}_{2} / \mathbf{S R}$ & $\begin{array}{c}\text { Air/ } \\
\text { Acetylene }\end{array}$ & 0.08 & 0.012 & 0.08-14 \\
\hline
\end{tabular}

2.3Measurement of the heavy metal concentration:

The digestion process using for determination the concentration levels of heavy metals in the samples of seminal fluid in two groups of patients with infertility and in normal group with fertility.

\subsection{Atomic absorption spectroscopy AAS}

Atomic absorption spectroscopy (AAS) is a technique for measuring quantities of chemical elements present in environmental samples by measuring the absorbed radiation by the chemical element of interest. This done by reading the spectra produced when the sample is excited by radiation (14). 
The atoms absorb ultraviolet or visible light and make transition to higher energy levels. Atomic absorption methods the amount of energy in the form of photons of light that are absorbed by sample (15). A detector measures the wavelengths of light transmitted by the sample. And compares them to the wavelength which originally passed through the sample(14). The technique make use of absorption spectrometry to assess the concentration of an analytic in a sample it requires standards with known analytic content to establish the relation between the measured absorbance and the analytic concentration and relies therefore on the beer-lambert low (16).

\section{Results}

The heavy metals concentrations in azoospremia and oligospremia patients comparison with fertile men (control group). The study was showed significant different $\mathrm{p}<0.005$ in all heavy metals obtained significant increase in (lead $\mathrm{Pb}$, magnesium $\mathrm{Mg}$, cadmium $\mathrm{Cd}$, iron $\mathrm{Fe}$, chromium $\mathrm{Cr}$, copper $\mathrm{Cu}$ and cobalt $\mathrm{Co}$ ) comparison with control group at following figures:

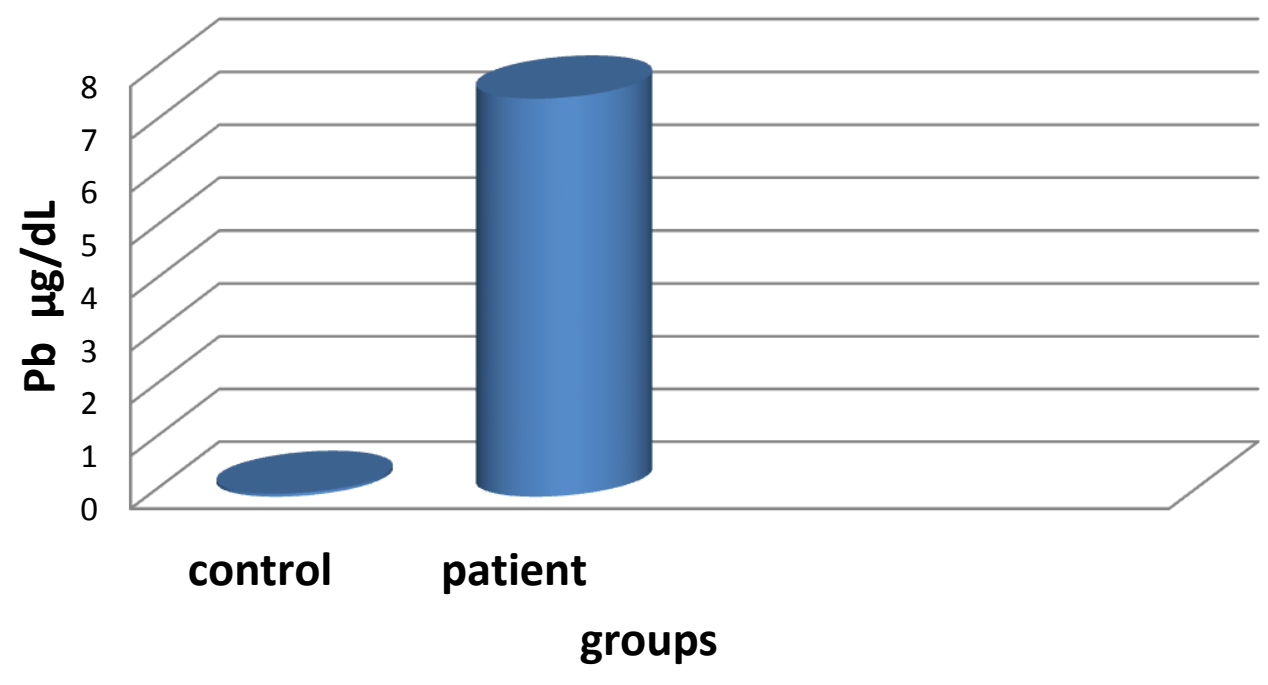

Figure (3-1) the comparison of lead concentration in $\mu \mathrm{g} / \mathrm{dl}$ in semen between patient group (infertile men) with control group (fertile men). Significant different $\mathbf{p} \leq \mathbf{0 . 0 5}$ between two group patient and control group. 


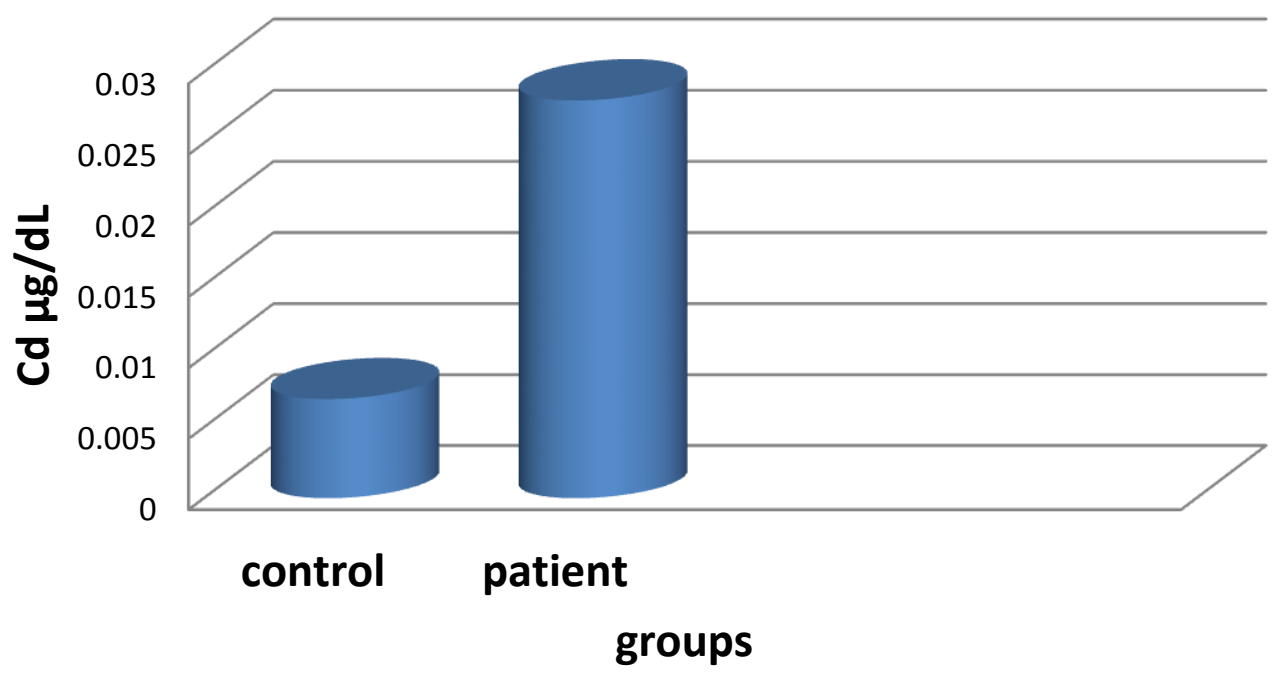

Figure (3-2) the comparison of cadmium concentration in $\mu \mathrm{g} / \mathrm{dl}$ in semen between patient group (infertile men) with control group (fertile men). Significant different $\mathbf{p} \leq \mathbf{0 . 0 5}$ between two group patient and control group.

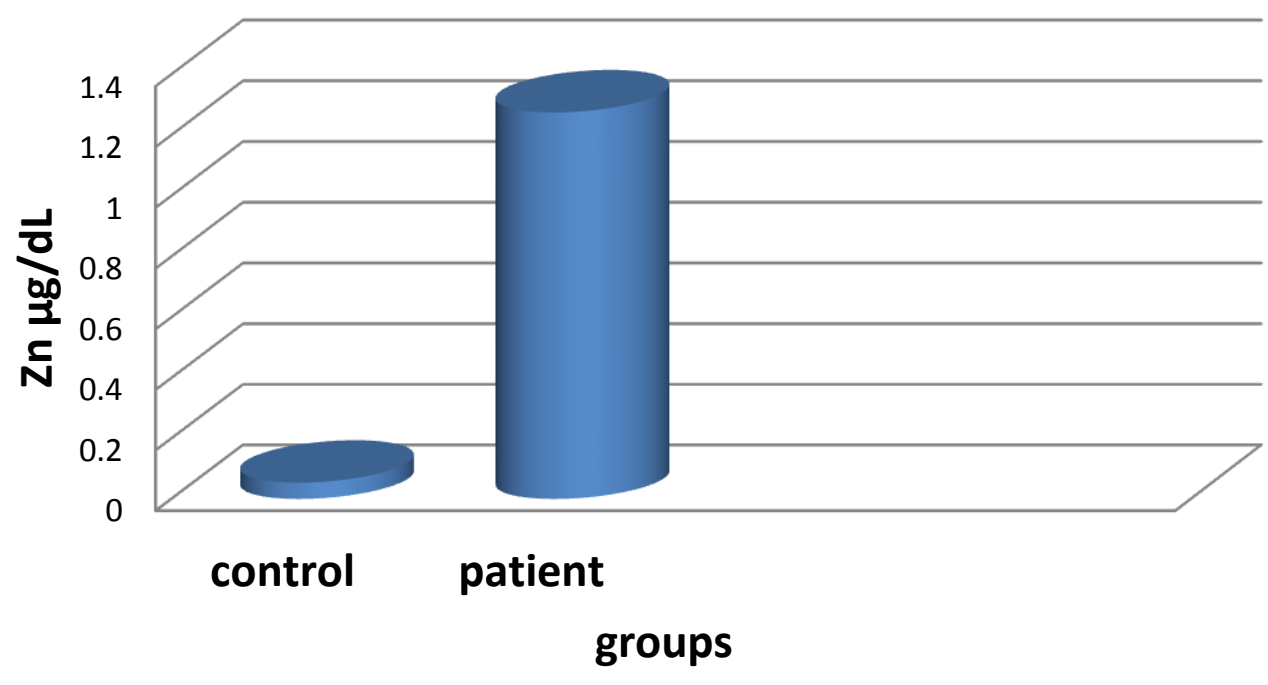

Figure (3-3) the comparison of zinc concentration in $\mu \mathrm{g} / \mathrm{dl}$ in semen between patient group (infertile men) with control group (fertile men). Significant different $\mathbf{p} \leq \mathbf{0 . 0 5}$ between two group patient and control group. 


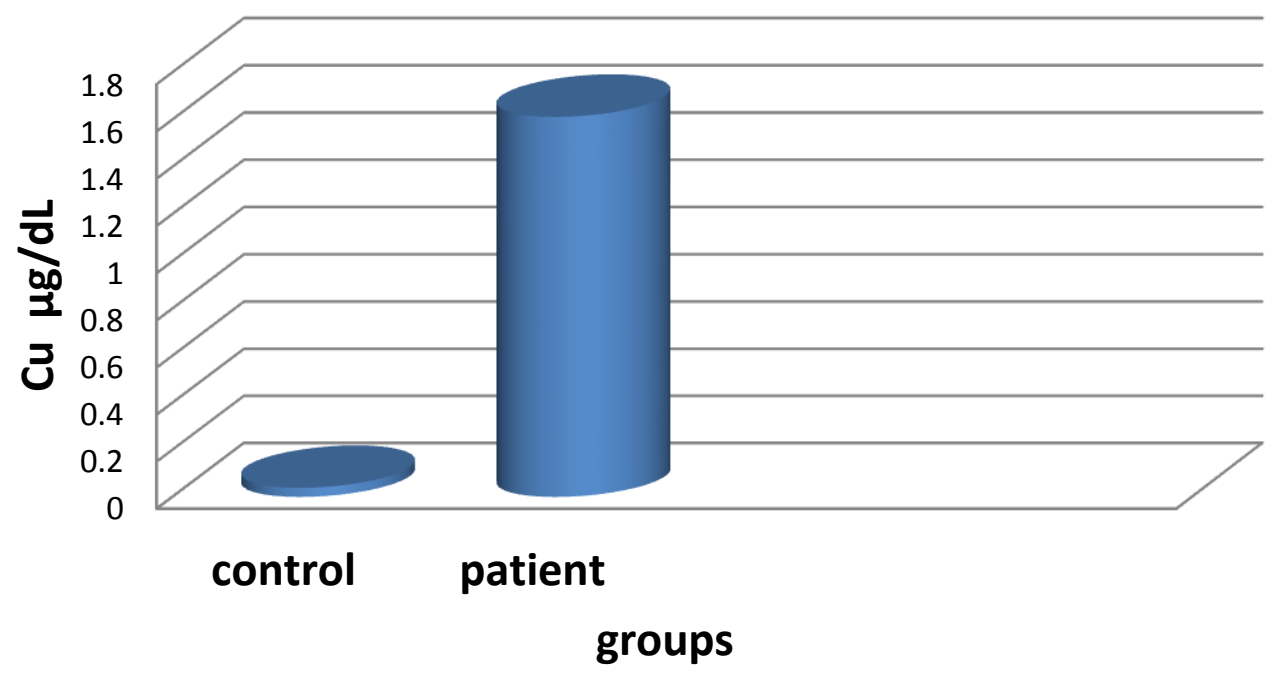

Figure (3-4) the comparison of copper concentration in $\mu \mathrm{g} / \mathrm{dl}$ in semen between patient group (infertile men) with control group (fertile men). Significant different $\mathbf{p} \leq \mathbf{0 . 0 5}$ between two group patient and control group.

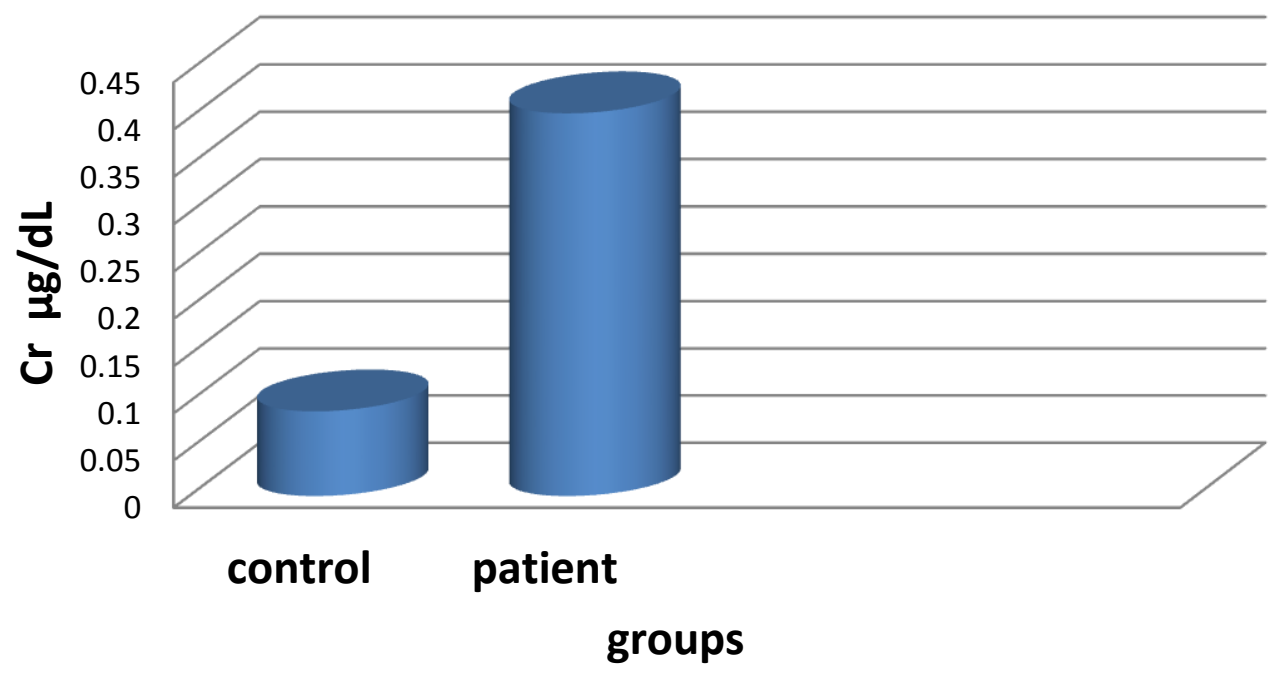

Figure (3-5) the comparison of chromium concentration in $\mu \mathrm{g} / \mathrm{dl}$ in semen between patient group (infertile men) with control group (fertile men). Significant different $\mathbf{p} \leq \mathbf{0 . 0 5}$ between two group patient and control group. 


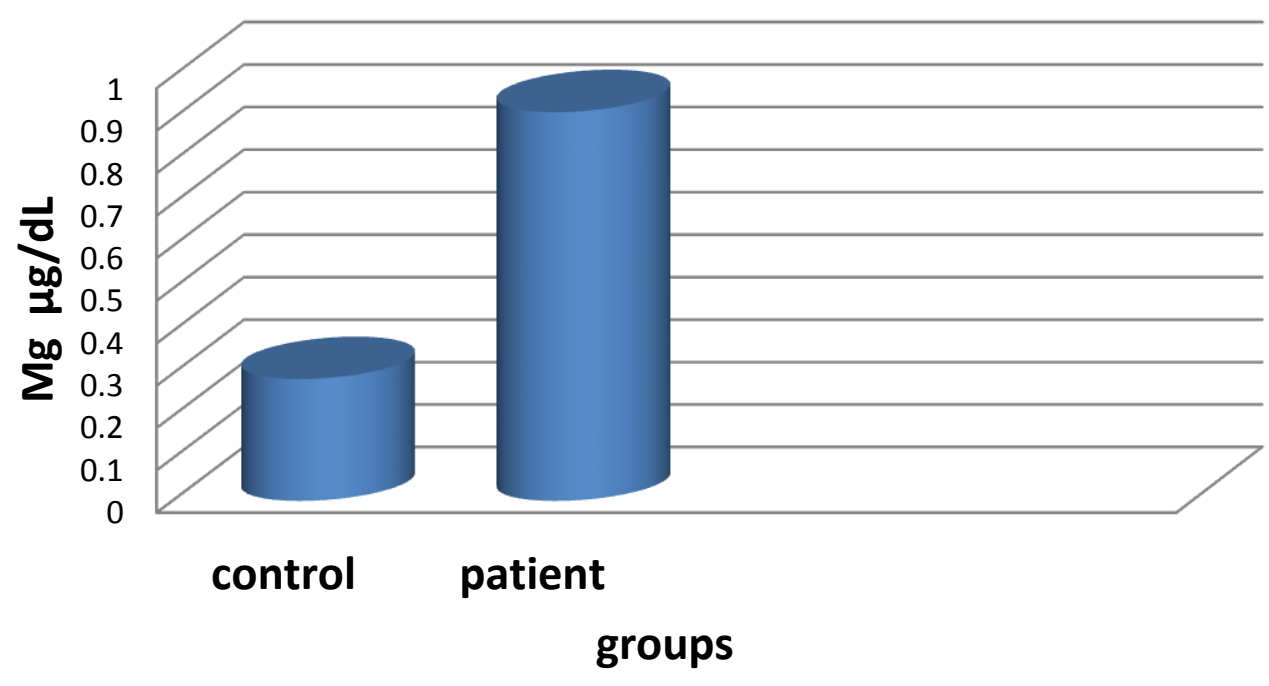

Figure (3-6) the comparison of magnesium concentration in $\mu \mathrm{g} / \mathrm{dl}$ in semen between patient group (infertile men) with control group (fertile men). Significant different $\mathbf{p} \leq \mathbf{0 . 0 5}$ between two group patient and control group.

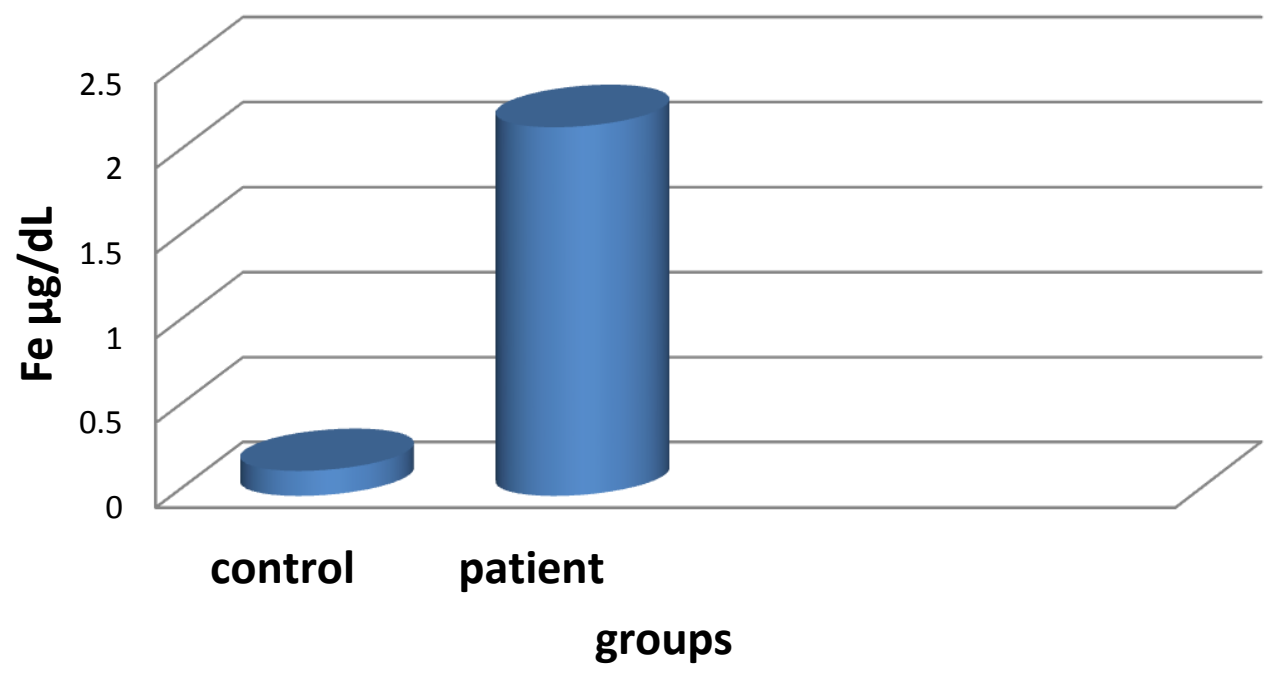

Figure (3-7) the comparison of iron concentration in $\mu \mathrm{g} / \mathrm{dl}$ in semen between patient group (infertile men) with control group (fertile men). Significant different $\mathbf{p} \leq \mathbf{0 . 0 5}$ between two group patient and control group. 


\section{Discussion}

This study working on samples from tow group of men fertile and infertile to estimation level concentration of heavy metals in samples tow cases.

The seminal fluid obtained from 100 men including infertile and control group. Their ages varied 18 to 49 years, thus covering the entire span of the reproductive years. Seminal fluid samples were investigated for the possible relationship between trace metals ( $\mathrm{Cd}, \mathrm{Pb}, \mathrm{Zn}, \mathrm{Cu}, \mathrm{Fe}, \mathrm{Mg}, \mathrm{Co}$ ) and infertility.

The results of study similar to the results of the research (15)and (16) who found that infertile men had higher concentration levels of lead when compared with the control group.

But results was different with the results of research (17)who found that concentration of lead in seminal plasma did not appear correlation with sperm parameters studies. Also statistical evaluation of lead concentration in seminal plasma among two groups infertile males and fertile males reflected no statistically significant variation in relation to infertility.

\section{Conclusion:}

Infertile men showed lower sperm concentration and lower motility, lower proportions of normal sperm morphology than fertile control. With patients groups differences in these parameters are prominent also.
The concentration levels of trace elements in patients group with infertility were higher than concentration levels in control group fertile men.

\section{References}

1.Geidam AD, tawe kdt, Adebayo AEA ET AL. hormonal profile of men investigated for infertility at the university of Maiduguri in northern Nigeria. Singaporemed j, 2008; 49; 538-541.

2.demetrius jp, male infertility: diagnosis and treatment. $\mathrm{J}$ nurse pract, 2006; 2: 298-299.

3.Ekwere Pd, Archibong EE, Bassey EE et al. Infertility among Nigerian couples as seen in calabar. Port harcout med j, 2007; 2: 35-40.

4.mathur $\mathrm{N}$, pandey $\mathrm{G}$ and jain $\mathrm{GC}$. male reproductive toxicity of some selected metals: a review. J bio sci, 2010; 10: 396-404.

5.Opsahl ms, Dixon Ng, Robins Er and Cunningham ds Signle us. Multiple semen specimens in screening for male infertility factors. A comparison. Cambridge: Cambridge university press, 2000.

6.Paulson JD, Asmar P, Saffan DS. Mild and moderate endometriosis. Comparsion of treatment modalities for infertile couples. J Repod Med ,1991; 36: 151-5.

7.Alloway bj. Heavy metals in soils. New York: john wiley inc, 1990. 
8.Mendiola J., J. M. Moreno, M. Roca, N. Vergara-Juarez, M. J. Martine-

Garcia, A. Garcia-Sanchez, B. ElviraRendueles, S. Moreno-Grau, J. J. Lopez-Espin, j. Ten, R. Bernabeu and AM. Torres-Cantero, 2011.

9.Rowe PJ, Comhaire FH, Hargreave TB and Mellows HJ (eds) WHO manual for the standardized investigation and diagnosis of the infertile couple. Cambridge University Press, Cambridge, 1993.

10.Joffe, M, Infertility and environmental pollution. Advances in Bioscience and biotechnology,2011; 2: 182-197.

11.Talisman, S, B. Colak, A. Pizent, Jurasovic and P Cvitkovic, Reproductive toxicity of low-level lead exposure in men. Environ Res, 2007;105: 256-266.

12.Goyer RA and Cherion MG. Ascorbic Acid and EDTA Treatment of Lead Toxicity in Rats. Life Science, 1979; 24: 433-438.
13. Rowe PJ, Comhaire FH, Hargreave TB and Mellows HJ (eds) WHO manual for the standardized investigation and diagnosis of the infertile couple. Cambridge University Press, Cambridge 1993.

14.Harnly j. m. multielement atomic absorption with a continuum source, anal. Chem, 1986; 58: 933-943.

15.Ali R, Birsen A, Hhan O, Bulent A, Hamdi O, Tevfik G. high levels of cadmium and lead in seminal fluid and blood of smoking men are associated with high oxidative stress and damage in infertile subjects 2007.

16.Spomenka T, Petra C, Jasna J, Alica P, Mirjana G, And Boris R, semen quality and reproductive endocrine function in relation to biomarkers of lead, cadmium, zinc and copper in men, 2000;108: 45-50.

17.Nahla M Tawfiq, Zina A Marrow, Basil Y Salah. Trace elements in the serum and plasma and their relationship to infertility in Iraq males. Alkindy Col Med J,2007;1: 11-14. 


\section{دراسة التأثيرات الانجابية لبعض العناصر النزرة على العقم عند الرجال في محافظة ذي قار/ العراق ملاك حريز نعيم}

ايناس صالح جواد

ساجد حسن كزار

\section{الخلاصة}

العقم يعرف بانه عدم الانجاب لمدة سنة كاملة بدون استخدام موانع حمل ويقسم الى نوعين ثانوي يعرف بانه

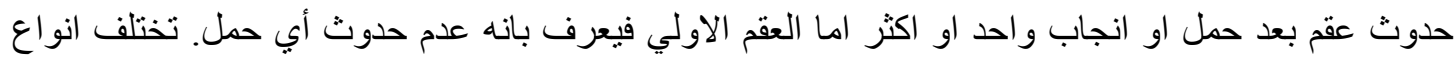

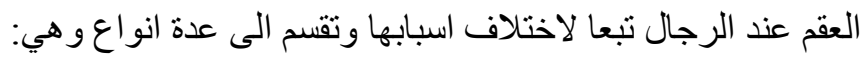

كما يمثل مرض العقم عند الرجال أحدى المشاكل الصحية كبيرة وان الزيادة المفرطة في تركيز العناصر النزرة مثل الرصاص و الكادميوم و الزنك و النحاس و الكروم و الكوبلت و المغنيسيوم و الحديد يمكن أن تشكل احد عو امل التل المؤثرة في العقم عند الرجال.

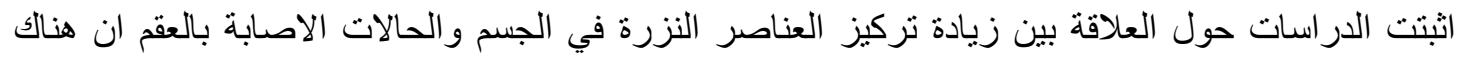

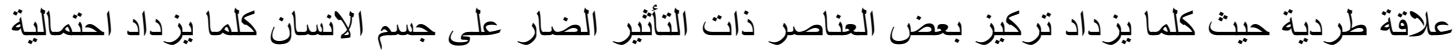
حدوث عقم بسبب النتوه الحيامن. أجريت الدراسة الحالية على أربع وثلاثون رجل عقيم تتراوح أعمار هم بين (9 (9 ـــ ) سنة وستة عشر رجل

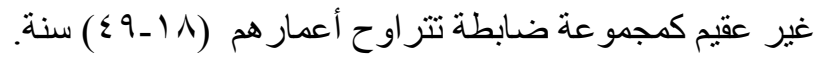

تم قياس تر اكيز العناصر النزرة الرصاص و الكادميوم و الزنك و النحاس و الكروم و الكوبلت و المغنيسيوم و الحديد

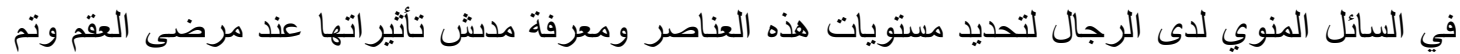
قياس تركيز العناصر الثقيلة باستخدام جهاز الامتصاص الفياص الذري.

تم استخدام طريقة الهضم لغرض تحضير العينات لغرض القياس تراكيز العناصر النزرة لكون الجهاز

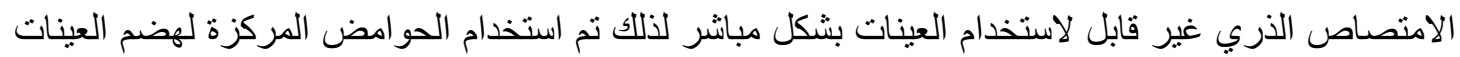

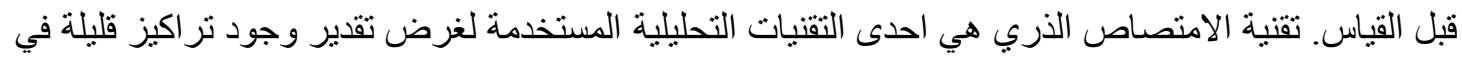

أي نوع من العينات سو اء كيميائية او عينات بايلوجية مثل الئل المصل الدم او السائل النوي او غيرها. أظهرت النتائج زيادة في تر اكيز عناصر النزرة وخاصة عنصر الرصاص أعلى من بقية العناصر الأخرى. كما ان الدراسة اظهرت زيادة تركيز العناصر المشمولة بالدراسة في حالة الاشخاص الذين يعانون من العقم الاولي مقارنة بالاشخاص الذين يعانون زباد من العقم الثانوي وكما تبين النتائج:

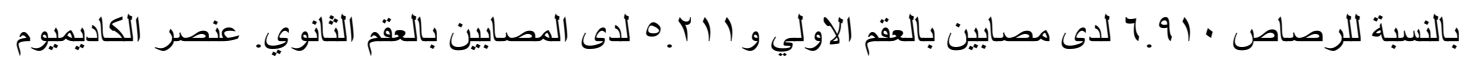

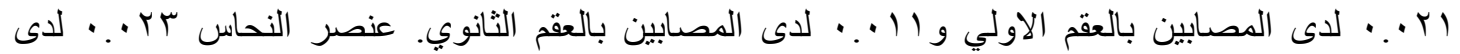

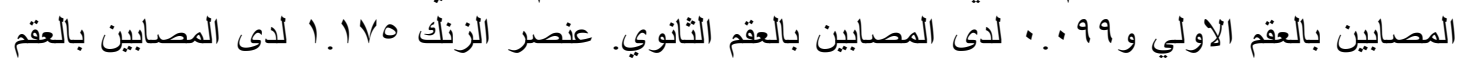

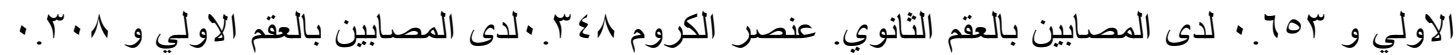

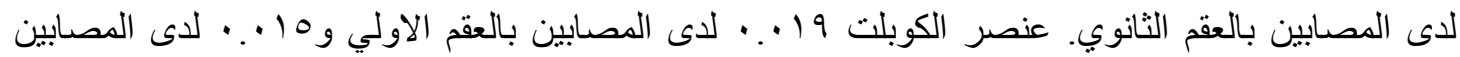

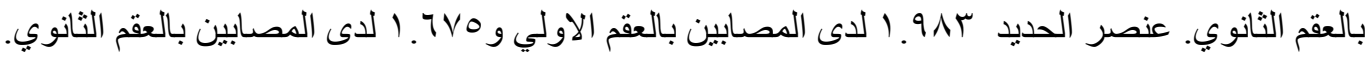

